\title{
Androgen Activity Inhibition
}

National Cancer Institute

\section{Source}

National Cancer Institute. Androgen Activity Inhibition. NCI Thesaurus. Code C41524.

Androgen Activity Inhibition involves interference with, such as receptor binding, or restraint of the biological function of biochemical substances (androgens) secreted by the testes that have a specific regulatory effect on the activity of cells involved in development and maintenance of male sex characteristics. 